"

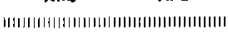

\title{
$\mathrm{Ni}$ 基合金のS偏析による高温脆化
}

今村元昭*

\section{High Temperature Embrittlement of a Ni-Base Alloy by Sulfur Segregation}

\section{Motoaki Imamura}

\begin{abstract}
Synopsis
Nimonic Alloy $75(\mathrm{Ni}-20 \mathrm{Cr}-0.5 \mathrm{Ti}-0.05 \mathrm{C})$ containing $50 \mathrm{ppm}$ sulfur exhibited poor ductility in the vicinity of $1000^{\circ} \mathrm{C}$. Auger spectrum from this fracture surface indicated that intergranular appearance areas were highly enriched in sulfur by a factor of 1600 . Small amounts of added magnesium extremely reduced the level of free sulfur and improved the intergranular ductility. High temperature ductility also was improved with increase the spacing of grain boundary carbides. A small addition of boron seems to change the morphology of grain boundary carbides.
\end{abstract}

\section{1. 緒}

\section{言}

$\mathrm{Ni}$ 基合金の熱間加工性に及ぼす $\mathrm{S}$ の影響につ いてはよく知られており,最近では Auger 分析に よって粒界におけるSの偏析状態1)-3) も明かにさ れている。従来Sは粒界に偏析して低融点化合物 を生成するとされてきたが，Ni-S の状態图上， 20ppm のSでは $\mathrm{Ni}_{3} \mathrm{~S}_{2}$ を生じないにもかかわら ず実際には著しい粒界脆化をひき起すことが報告 されている2゙。このよらにSは原子状態で粒界に 偏析して粒界の表面エネルギーを下げ，ボイドの 発生を容易にするるのと考えられる。

しかし, 実用合金でS偏析による粒界脆化機構 を研究した例は極めて少く，粒界炭化物や $\gamma^{\prime}$ の析 出が関与するため, 現象はかなり複雑である。

ここでは, $\mathrm{Ni}$ 基合金の中で最す単純な合金系の

昭和61年 2 月 25 日 受付

大同特殊鋼㧣研究開発本部
Nimomc Alloy $75(\mathrm{Ni}-20 \mathrm{Cr}-0.5 \mathrm{Ti}-0.05 \mathrm{C})$ をと りあげ，高温で発生させた粒界割れ表面のオーシ ×分析を行い, 高温延性低下の要因について検討 した。

\section{2. 実 験 方 法}

実験に使用した合金 A，Bの化学成分を Table

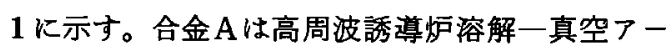
ク溶解を経た 2 ton インジットを 1200 C C で $16 \mathrm{~h} の$ ンーキング後プレス鍛造によって 中 300 まで鍜伸 したものである。Bは合金 Aの一部を $50 \mathrm{~kg}$ 真空 誘導炉で再溶解する際に微量の $\mathrm{Mg}, \mathrm{Zr}, \mathrm{B}$ を添 加した $30 \mathrm{~kg}$ インゴットで，同様のンーキング処 理を行った。

まず，熱間加工性は各素材から削り出した $\phi 6.4 \times 110 \ell$ の試験片（Fig. 1a）を用いてグリー ブル試験で評価した。クリーブル試験における熱 サイクルは Table. 2 に示したよ5に, 昇温と降温 方式とし, 降温試験における最高加熱温度はンー 
Table 1. Chemical compositions of investigated materials-Nimonic 75 .

(wt \%)

\begin{tabular}{c|c|c|c|c|c|c|c|c|c|c|c|c|c|c}
\hline $\begin{array}{c}\text { Alloy } \\
\text { desig. }\end{array}$ & $\mathrm{C}$ & $\mathrm{Si}$ & $\mathrm{Mn}$ & $\mathrm{P}$ & $\mathrm{S}$ & $\mathrm{Ni}$ & $\mathrm{Cr}$ & $\mathrm{Ti}$ & $\mathrm{Fe}$ & $\mathrm{Zr}$ & $\mathrm{Mg}$ & $\mathrm{B}$ & $\mathrm{O}$ & $\mathrm{N}$ \\
\hline $\mathrm{A}$ & 0.12 & 0.55 & 0.61 & 0.004 & 0.005 & $\mathrm{Bal}$ & 19.56 & 0.46 & 0.44 & N.D. & N.D. & N.D. & 0.0016 & 0.007 \\
\hline $\mathrm{B}$ & 0.11 & 0.58 & 0.57 & 0.003 & 0.005 & Bal. & 19.78 & 0.43 & 1.38 & 0.03 & 0.019 & 0.0038 & 0.0016 & 0.006 \\
\hline
\end{tabular}

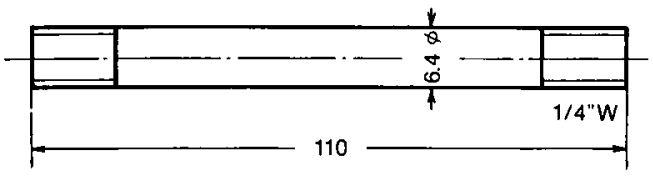

a) Gleeble tensile

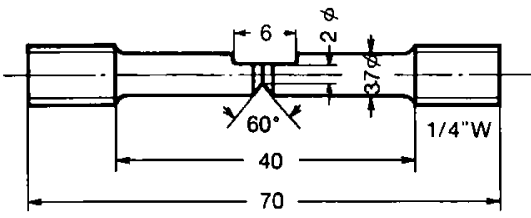

b) Notched tensile (for AES analysis)

Fig. 1. Geometry of test specimens (mm).

Table 2. Heat cycles for test specimens.

\begin{tabular}{c|c|c}
\hline & Heating & Cooling \\
\hline $\begin{array}{c}\text { Gleeble } \\
\text { tensile test }\end{array}$ & & \\
\hline $\begin{array}{c}\text { AES } \\
\text { analysis }\end{array}$ & & \\
\hline
\end{tabular}

キング温度と同じ1 $200^{\circ} \mathrm{C}$ とた。また，引張速度

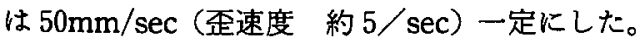

オージェ分析用の試験片はFig. 1 b)に示すよ らな切欠付きとし，切欠部に熱電対をスポット溶 接できるよう側面を平らにした。グリーブルの降 温試験の場合と同様の熱サイクルを与えた後，切 欠部を10倍の拡大鏡で観察しながら，約 $1 \mathrm{~mm} / \mathrm{sec}$ の速さで引張ることによって切欠底にクラックを 発生させ，直ちに䉓流を切りェてを吹さつけ急冷 した。両端を切り離してそのままオージェ分析装 置に入れ，高真空下 $\left(2.5 \times 10^{-10}\right.$ Torr $)$ ，液体窒素

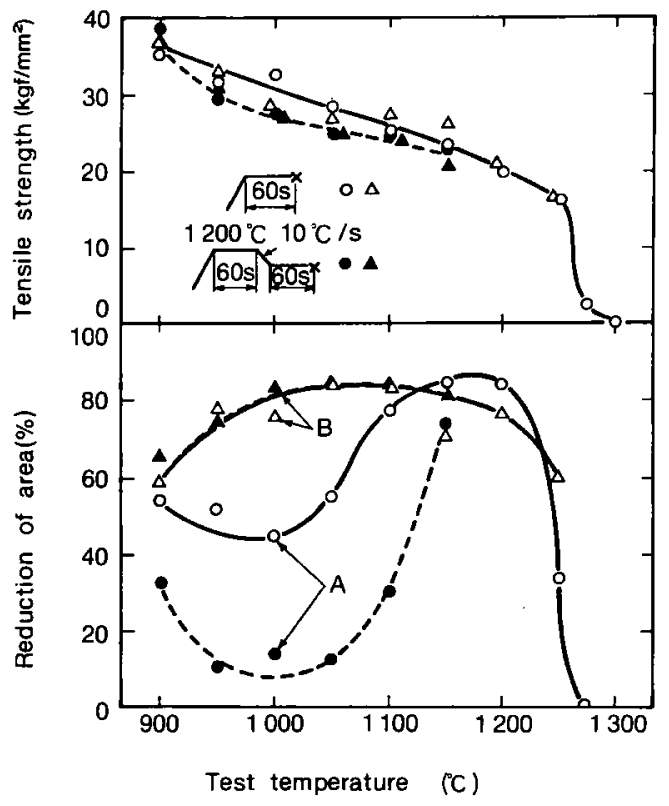

Fig. 2. Comparison of hot ductility of Alloy $\mathrm{A}$ and $\mathrm{B}$.

温度で破断させ，その新生破面についてオーシェ 分析を行った。分析装置は Physical Electronics Model 590 を使用した。

\section{3. 実験結果と考察}

\section{1 熱 間 加 I 性}

合金 A及びBのグリーブル試験結果をFig. 2 に示す。 $1000^{\circ} \mathrm{C}$ 附近で合金Aの校り値は著しく低 下しており，とくに降温試験の場合に顕著である。 これに対して合金Bは鋳塊であるにるかかわら ず，全体に絞り値が高く，熱サイクルによる低下 あ見られない。Photo. 1 にグリーブル試験後のミ ク口組織を示すょ い合金Aでは粒界に沿って割れが進展しており， 合金 Bの場合と異なり，粒界周辺の再結晶した領 域は極く僅かである。これは，引張りによって生 


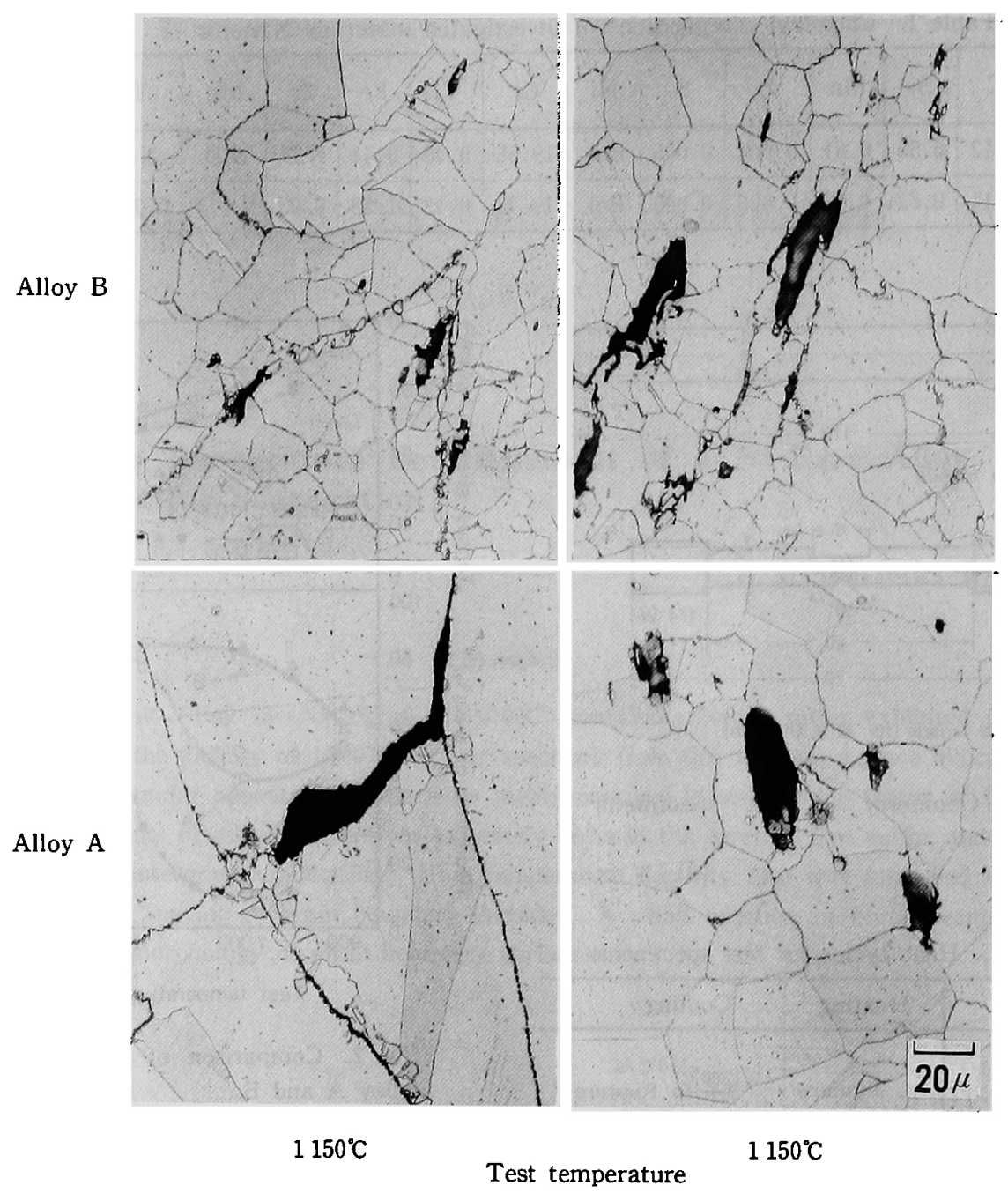

Photo. 1. Typical microstructures of specimens after tensile tests.

こた粒界の応力集中が再結晶によって爰和されな い間にクラックが伝播したことを示している。 $1150^{\circ} \mathrm{C}$ 以上で合金 $\mathrm{A}$ の筊り值は合金 $\mathrm{B}$ と同程度 にまで回復しており，ミク口組織的にも合金 $\mathrm{B}$ と ほとんど同様である。粒内全体に再結晶が進み， $\mathrm{MC}$ 炭化物の周りに生したボイイトは先端が丸味を 帯びて応力緩和されている様子がうかがわれる。

\section{2 粒 界 偏 析}

Fig. 3 に合金 Aのクラック発生温度 $1050^{\circ} \mathrm{C}$ に 扣けるオーシェ分析結果を示す。粒界破面には明 加 S (152ev) の他に, C (272ev), Ti (418ev), $\mathrm{Cr}(529 \mathrm{ev}), \mathrm{Ni}(848 \mathrm{ev})$ のピークが現れている。 ピーク高さは表面の原子濃度に比例するすの之仮

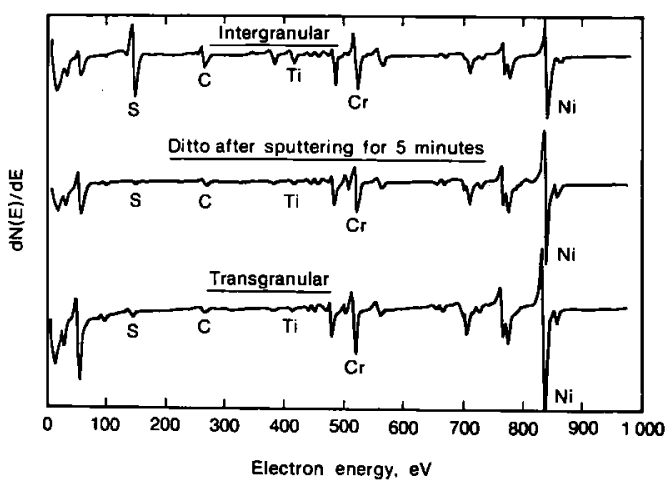

Fig. 3. Typical spectra of AES analysis for fracture surface of Alloy A (crack initiation at $1050^{\circ} \mathrm{C}$ ). 
定されるが，この前提に立てば合金Aの粒界には $\mathrm{S}$ が著しく濃化していることになる。この表面に フルゴンイオンによるスパッタリング処理を 5 分 間行うと，S，C，Tiのピークは著しく低下して， 粒内破面のスペクトルとほとんど同様になる。こ のスパッタリング処理速さは $200 \AA / \min (1000 \AA$ の $\mathrm{Ta}_{2} \mathrm{O}_{3}$ 簿のスパッタリンダ所要時間 $10 \mathrm{~min}$ 上 り計算）とわかっているので，これを基準にする と，Sの濃化深さは粒界表面から高々 $1000 \AA$ 程度 となる。

$$
\text { スパッリング時間に対して各元素のピーク高 }
$$

さをプロットすると，表面からの元素の濃度プロ ファイルが求められる。Fig.4と5はクラック発 生温度が $1000^{\circ} \mathrm{C} \sim 1150^{\circ} \mathrm{C}$ に打ける濃度ブロフ イルを示している(各元素のピークはNiのピー クとの比率で表わされている)。これらのプロフフ イルを比較してわかることは，クラック発生温度 が低い程, 粒界近傍におけるSの濃度勾配は急峻 となるが，濃化深さは次第に浅くなる㑯向が認め られることである。粒界表面のSピークは $1050^{\circ} \mathrm{C}$ で最大となり，高温になる程低下しているが，こ れはSのマトリックスへの固溶度が温度と共に増 加することと対応するものと考学られる。

つぎに注目される点は，Tiは 較的大きいにもかかわらず，表面に打ける濃化程
度がSに比べて小さいことである。このことは， $\mathrm{Ni}$ 中への Ti の固溶度が大きく, Ti の活量が比較 的小さいため，Sの固着作用か弱いこと，したが って0.5\%程度の $\mathrm{Ti}$ の添加では高温延性の向上 はあまり期待できないものと考えられる。

\section{3 粒界表面の $\mathrm{S}$ 祣度と高温延性}

合金Aのオージェスペクトルのピーク高さか ら，相対感度俰数4を用いて表面の原子濃度を計 算し, Fig. 6 Kグリーブル試験の絞り值と対比し

Approximate depth sputtered (nm)

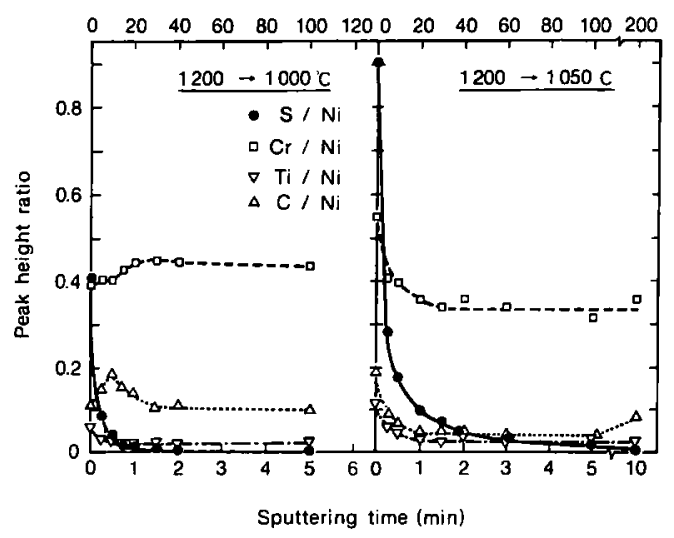

Fig. 4. Concentration-depth profiles for alloying elements in Alloy A.

Approximate depth sputtered $(\mathrm{nm})$

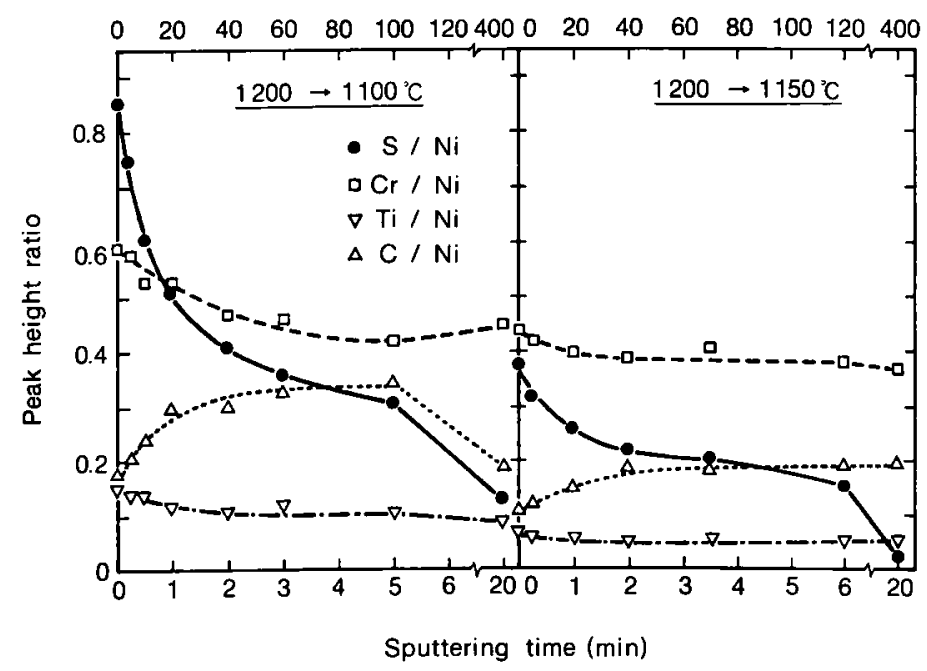

Fig. 5. Concentration-depth profiles for alloying elements in Alloy A. 


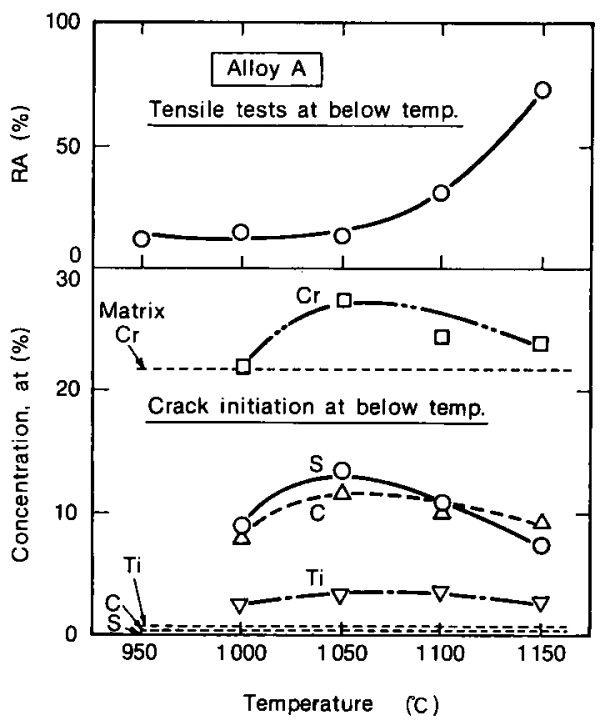

Fig. 6. Relation between hot ductility and surface compositions for cracks.

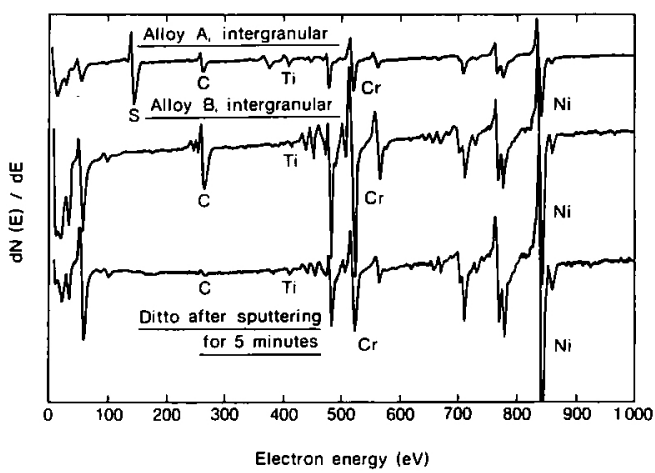

Fig. 7. Typical spectra of AES analysis for fracture surfaces of Alloy A and B (crack initiation at $1050^{\circ} \mathrm{C}$ ).

て示した。この図によると, $1050^{\circ} \mathrm{C} て ゙ \mathrm{~S}, \mathrm{C}, \mathrm{Ti}$, $\mathrm{Cr}$ とる最も濃化割合が大きいが，この温度附近で 延性低下る大きことから，高温延性にこれらの 元素が関与していることは確かのようである。と りわけ，Sの濃化が著しく，表面濃度は 14.2atom \%でマトリックス (0.009atom \%)の1600倍に達 する。Cr と Cの原子濃度比は 2： 1 と $\mathrm{Cr}_{7} \mathrm{C}_{3}$ の原 子構成比 $2.3: 1$ に注ぼ近いこと, また後述の電子 回折結果から， $\mathrm{Cr}_{7} \mathrm{C}_{3}$ が析出しているすのと推定 される。Ti の濃度は 3.3atom \%にすぎず, TiS を

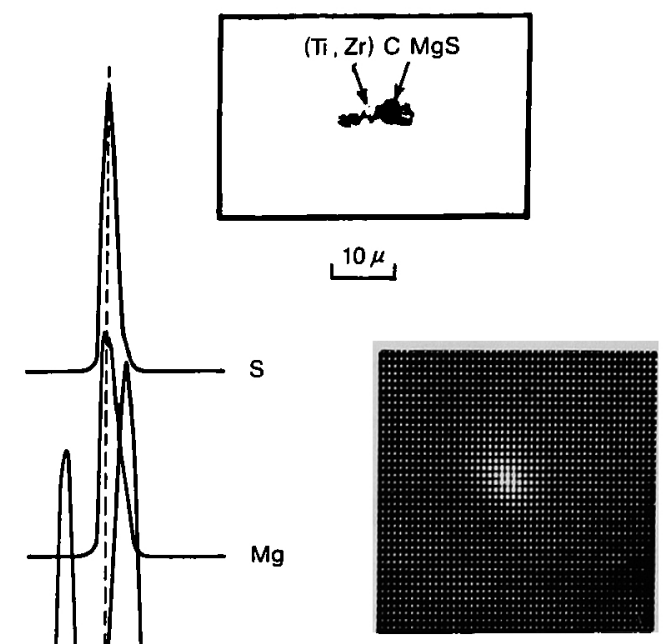

S Auger image

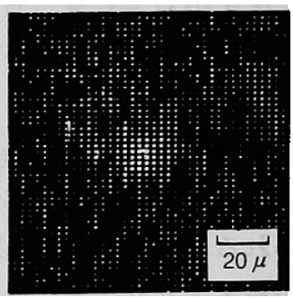

$\mathrm{Mg}$ Auger image

Fig. 8. Results of EPMA analysis and Auger images of inclusions in Alloy B.

形成するには不分である。また, Fig. 2 に示した 引張強さはこの温度附近で特異な変化を示してい ないことから，溶融相の存在は考えにくい。

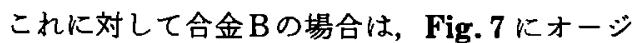
エ分析結果を示すように, Sのピークは全く表れ ていない。C， Ti， Crのピークが明かに見られる ことから粒界破面であると判断されるが，この破 面を 5 分間スハッッタンクするる， C, Ti， Crの ピークは低下し，粒内破面の場合とほとんぞ同じ になる。

Fig. 8 は合金 Bの粒内に見られた介在物の EPMA 分析結果を示す。 $Z r, T i$ の炭化物に隣合っ てMgS として存在していることから凝固時に生 成したことが，らかがわれる。また，同図中に示 したよ5に，破面のオージェイメージ写真でも同 様に MgS としての存在が確諗された。

以上の結果から，合金 $\mathrm{B} の \mathrm{~S}$ は $\mathrm{MgS}$ として固 


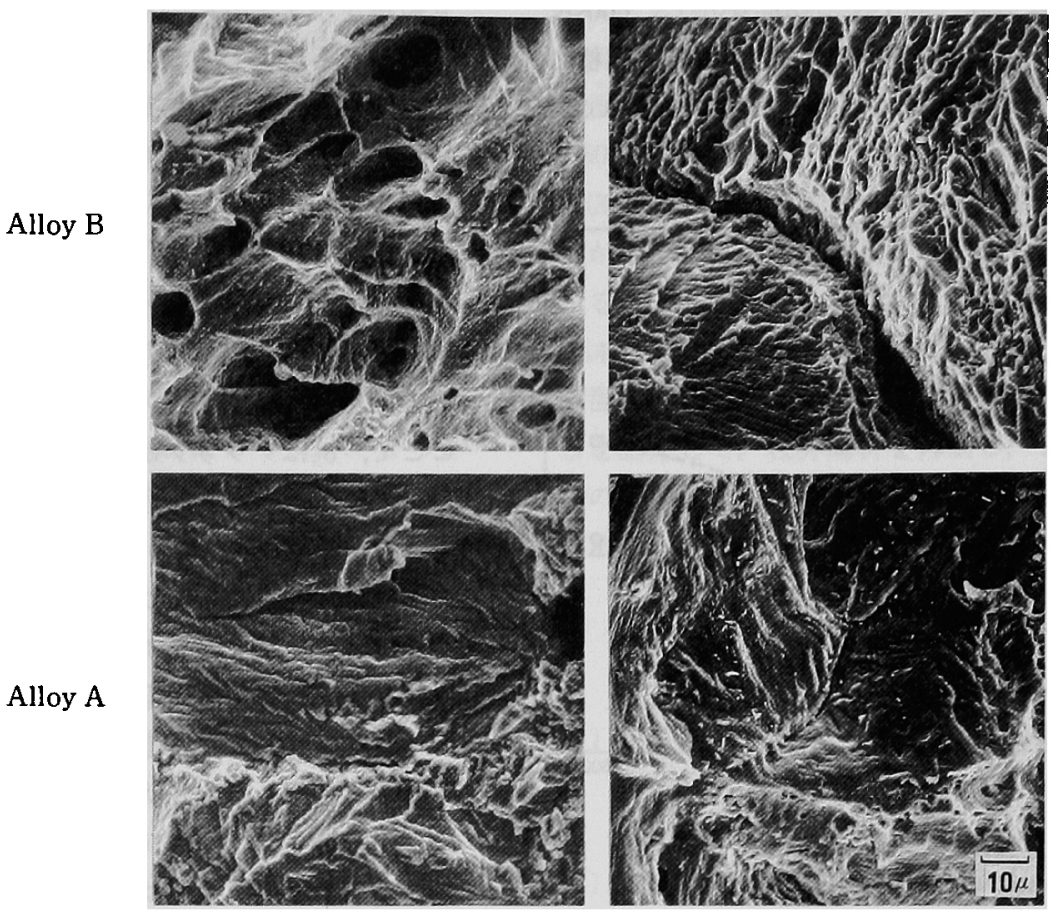

Gleeble test specimens ruptured at $1050^{\circ} \mathrm{C}$
AES analysis cracks initiated at $1050^{\circ} \mathrm{C}$

Photo. 2. Fracture surfaces of Alloy A and B.

定化され，粒界（この場合は凝固時の粒界）では $\mathrm{S}$ の偏析が存在しないため, 高温脆化が生じない ものと結論できる。

\section{4 粒界析出相の形態と高温延性}

Photo. 2 はオージェ分析面とグリーブル試験 後の破面を対比して示した。高温脆化を示す合金 $\mathrm{A} の 1050^{\circ} \mathrm{C}$ に打ける破面は, グリーブル試験扰よ びオーシェ分析の場合とも明かに粒界より破断乙 ている。合金 Bの場合，グリーブル試験後の破面 は典型的なディンプル・パターンを伴った延性破 面であるが，オージェ分析面は粒界破面である。 このことは，Sが固定されて高温脆化が生じない 合金であっても，遅い需速度でクラックを発生ざ せれば，液体窒素温度で粒界破壊することを示し ており，粒界への炭化物析出がこれを助長したす のと考克られる。

合金Aのオージェ分析面から抽出した析出相の レプリカ電顕像とその電子回折バーンを Photo. 3 に示す。破面に短冊状に析出した相は,
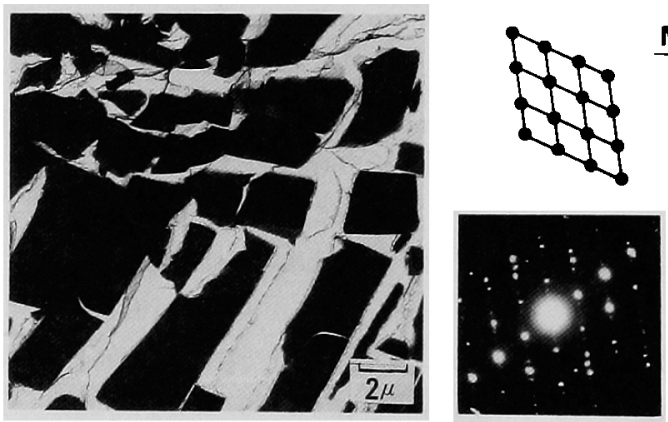

Photo. 3. Extraction replica from the crack surface initiated at $1050^{\circ} \mathrm{C}$ for Alloy A.

$\mathrm{M}_{7} \mathrm{C}_{3}$ であり,マトリックスの電解抽出残渣のX線 回折結果から女, 税密六方晶の $\mathrm{M}_{7} \mathrm{C}_{3}(\mathrm{a}=$

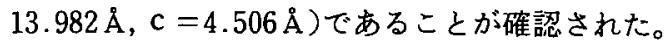

Fig.9は合金Aのグリーブル試験の絞り值に対 する高温保持時間の影響を見たるのである。

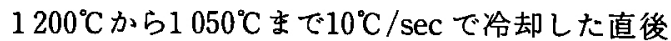
の絞り値は僅か $10 \%$ と低いが，その温度での保持 
時間が長くなる程，向上する傾向を示し， $600 \mathrm{sec}$ 保持後では約 $40 \%$ に達する。950 $\mathrm{C}$ の場合る同様の 傾向を示す。Photo. 4 Kグリーブル試験後のミク

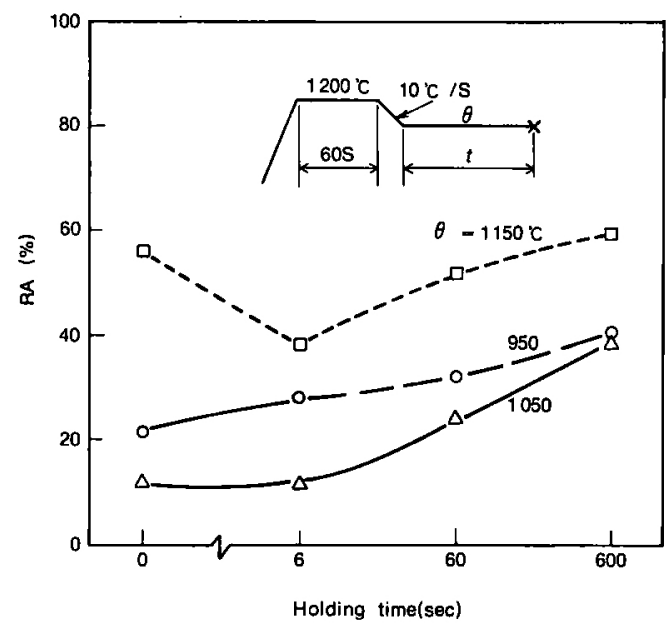

Fig. 9. Holding time and hot ductility.
口組織を示すよ5に, $1050^{\circ} \mathrm{C} \times 6 \mathrm{sec}$ では粒界に沿 って割れが卮播しているが, $600 \mathrm{sec}$ 保持後では粒 界に点緅した炭化物の周辺に発生したボイドは連 結しがたいように見える。これは，高温保持中に 粒界炭化物が成長して，粒子間谝が広くなったた めと考えられる。

粒界割れに対する析出粒子の役割については， 次のStroh の式占で説明される。

$$
\sigma_{\mathrm{s}} \geqq(12 \gamma G / \pi L)^{1 / 2}
$$

ここで, $\sigma_{\mathrm{s}}$ はクラックが生じるための最大㖣断応 カ, $\gamma$ はクラックの表面エネルギー, Gは剛性率, Lはすべり面の長さで，粒界析出相のある場合は 析出相の間隔と見なすことができる。この式から， 粒界析出粒子間 $L$ の増加によって $\sigma_{\mathrm{s}}$ が増大し，粒 界割れを生じ難くするものと考えられる。

一般任不純物による延性の低下については粒界 表面エネルギーから説明される。すなわち, 応力 の下で粒界に熱力学的に安定な半径 $\gamma$ のボィト が生成するための条件は次式6で表わされる。
Holding time : $6 \mathrm{sec}$

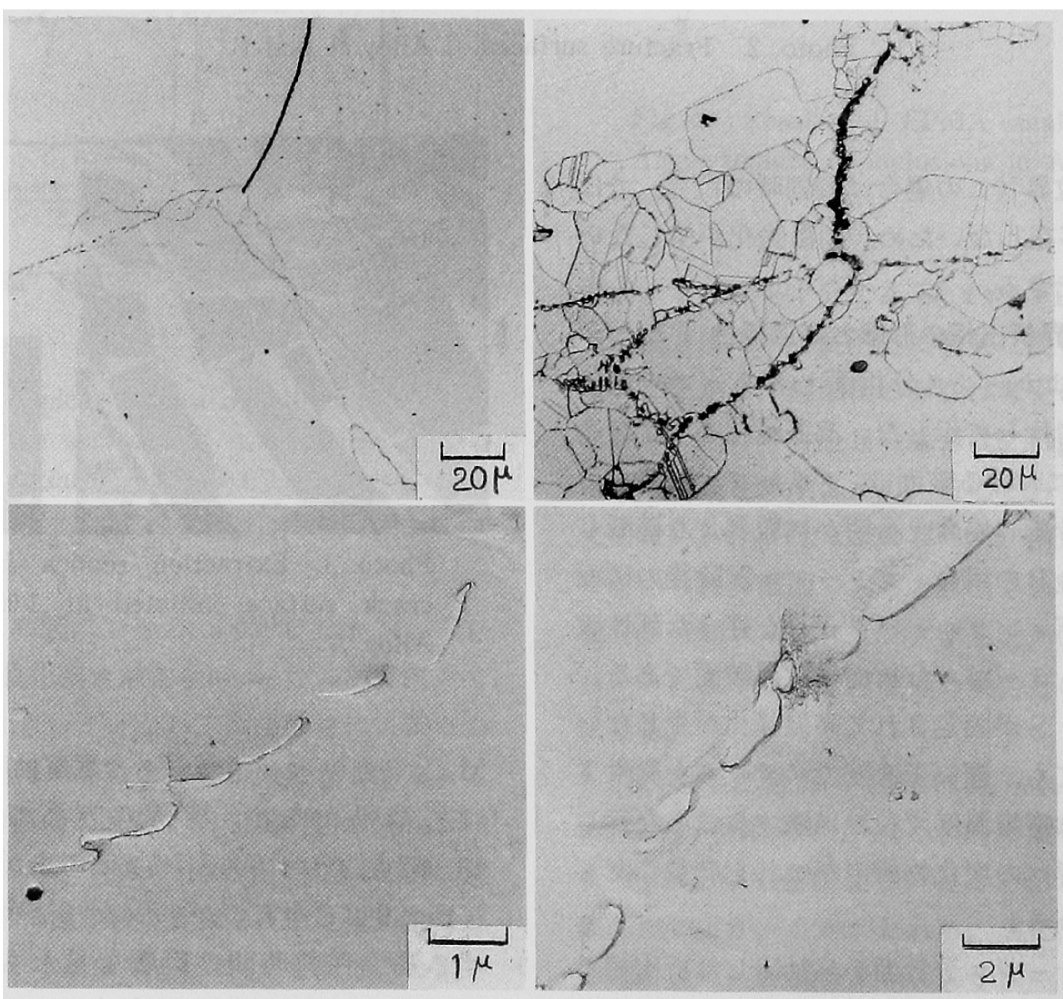

Photo. 4. Crack propagation in tensile test and grain boundary carbide morphology after holding at $1050^{\circ} \mathrm{C}$. 


$$
\gamma=2 \gamma_{\mathrm{s}} / \sigma
$$

ここで， $\gamma_{\mathrm{s}}$ は表面エネルギー， $\sigma$ は引張応力であ る。不純物の吸着によって表面エネルギーが低下 する注ど発生するボイドは微細となる。つまり， 微細なボイドが連結して大きなクラックに成長し て破断しやすいことを意味する。 粒界炭化物が介在する場合には、マトリックス と炭化物間の表面エネルギーがSの吸着によって 低下し，ボイドが発生しやすくなる。さらに，発 生したボイドが連結して成長しやすいかどらか は，粒界炭化物の形態に左右され、フィルム状か ら点棳した粒子状になると割れの伝播は遅延する ものと考えられる。

Johnson 等7)によるとBはマレージング鋼の時 効において粒界に析出した TiCとマトリックス 間に偏析して結合力を弱めるとしているが，彼等 のオージェスペクトルには Ti と同程度の S ビー クが認められることから，むしろS偏析によって 脆化したことが考えられる。

Doherty 等8) $60 \mathrm{ppm} の \mathrm{~S}$ 含む $\mathrm{Ni}-12 \mathrm{Al}$ -4Ta 合金の延性は溇量の Bの添加によって，粒 界に析出した Ta硫化物が球状化されるため向上 するものと考えており，粒界析出相の形態制御と いら点からあ， Bの添加は極めて重要であると考 亲らる。

4. 結

50ppmのS を含むNimonic 75 を対象に高温 で発生させた粒界割れ表面のオージェ分析を行 い，高温延性低下要因について検討した結果は次 の通りである。

（1）高温脆化温度で引張り，内部クラックを発 生させた後, 低温で破断させた粒界破面にはSの 偏析が著しく, 他にC, Ti, Crの偏析す認められ 万。
（2）クラック発生温度が低い程, 表面からの濃 度勾配は急峻となり，偏析深さは浅くなる。粒界

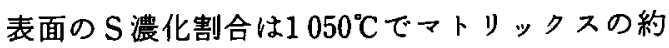
1600 倍に達する。

（3）高温延性は粒界の炭化物の形態がフィルム 状から粒状となり, 粒子間隔が広くなる程, 向上 する。

（4）高温脆化材に $\mathrm{Mg}$ 括よびBを添加すると 高温延性は著しく向上する。 MgはMgSとして Sを固定して，粒界偏析を抑制し，Bは粒界炭化 物の形態を粒状化する役割りを持つものと考えら れる。

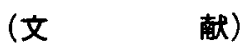

1) S. Yamaguchi, H. Kobayashi, T. Matsumiya and S. Hayami ; Met. Tech.,6 (1979), 170

2) C.L. White, J.H. Schneibel and R.A. Padgett ; Met. Trans., 14A (1983), 595

3) C.L. White and D.F. Stein ; Met. Trans., 9A (1978), 13

4) P.W. Palmberg, G.D. Riach, R.E. Weber and N.E. MacDonald ; Handbook of Auger Electron Spectroscopy (1972) [Physical Electron Industries]

5) C.W. Weaver ; Acta Met., 8 (1960),343

6) G.B. Thomas and T.B.Gibbons; Met. Tech., 6 (1979), 95

7) W.C. Johnson and D.F. Stein ; Met. Trans., 5 (1974), 549

8) J.E. Doherty, B.H. Kear, A.F. Giamei and C.W. Steinke; Grain Boundaries in Engineering Materials (1974), 619 